\title{
$\alpha$-Glucosidase Inhibitory Activity of Ethanolic Extract Gambier (Uncaria gambier Roxb) From Southeast Aceh As Antidiabetes
}

\author{
Vera Viena ${ }^{1,2}$ and Muhammad Nizar ${ }^{2}$ \\ \{veraviena@serambimekkah.ac.id\} \\ ${ }^{1}$ Laboratory of Chemical and Environmental Engineering, Universitas Serambi Mekkah, Aceh, \\ Indonesia \\ ${ }^{2}$ Department of Environmental Engineering, Universitas Serambi Mekkah, Aceh, Indonesia
}

\begin{abstract}
Plants continue to play an important role in the treatment of diabetes. Gambier (Uncaria gambier Roxb) is one of the plants used for commercial product as a betel meal for the Acehnese. In this research we studied the inhibition activity of $\alpha$-glucosidase enzyme toward gambier ethanolic extract as antidiabetes. The extraction of leaves, twigs and commercial gambier were performed by maceration method using ethanol solvent for 3 x 24 hour. Analysis of inhibition activity of $\alpha$-glucosidase enzyme from each extract was done using microplate-96 well method, then the $\mathrm{IC}_{50}$ value was determined. The results showed that the inhibition activity of alpha glucosidase enzyme against gambier ethanolic extract was giving positive result, in delaying the glucose adsorption, while the highest activity was found in gambier leaves of $96,446 \%$. The $\mathrm{IC}_{50}$ values of gambier leaves extract were compared to positive control of acarbose (Glucobay®) atwith ratio of $35,532 \mathrm{ppm}$ which equal to $0,262 \mathrm{ppm}$. In conclusion, the gambier ethanolic extract has the best inhibitory activity against the alpha glucosidase enzyme to inhibite the blood sugar level, which can be used as one of traditional herbal medicine (THM) product.
\end{abstract}

Keywords: $\alpha$-Glukosidase, Inhibitory Activity, Gambier, Antidiabetes.

\section{INTRODUCTION}

Metabolic disorder diseases such as Diabetes Mellitus (DM) was characterised by high blood glucose level or hyperglycemia because of insulin insufficiency and/or insulin resistance. It is predicted the affected DM people will increased from 171 million to 366 million in the year 2000 to 2030 [1]. The number of DM patients increases every year. The number of diabetics in Indonesia is expected to increase from 8.4 million people in 2000 to 21.3 million in 2030 [2]. According to the WHO [3], Indonesia ranks 4th highest in the world in number of DM patients, after China, India, and the United States of America (USA).

Among the several therapeutic approaches is retarding glucose absorption using inhibitors of carbohydrate-hydrolyzing enzymes such as $\alpha$-amylase and $\alpha$-glucosidase [4]-[6]. In 
developing counties with inadequate source of modern treatment, plants mainly utilized for treating diabetes [7].

Uncaria gambier (gambier), was a native Southeast Asian herbal plant mainly found in Indonesia and Malaysia. It's purpose was for astringent medicine, tanning, calico printing and dyeing. Uncaria gambier consists mostly of flovanol monomers such as (+)-catechin, (+)epicatechin and alkaloids [8]

In Indonesia gambier plants growth in various areas, including West Sumatra and Riau. These two areas are gambier production that have entered the export market, while the North Sumatra, Bengkulu, South Sumatra and Aceh production was only to meet the needs of local markets. In Aceh, gambier planting are very limited, due to the limited knowledge of the community about the benefits and methods of gambier processing [9]. The gambier planting in Aceh is concentrated in Southeast Aceh Regency, Darul Hasanah district with an area of approximately $200 \mathrm{Ha}$. Production centers are located in the village of Kute Panjang, Istiqamah using wet production method.

Until now, research on the inhibitory activity of Indonesian gambier as an alternative for antidiabetes is still scanty. Nevertheless, some studies of gambier as an antioxidant have been scientifically proven. According to [10] the commercial gambier from Tangerang Indonesia contains a catechin compound which act as bioactive compound with high activity for DPPH inhibition but moderate activity for inhibiting $\alpha$-glucosidase in vitro. Rauf, Santoso, \& Suparmo [11], have studied the antioxidant activity of gambier from Yogyakarta using three types of solvents [aquadest:ethanol (1:1), ethanol;ethyl acetate (1:1), and ethyl acetate], followed by purification using Sephadex LH-20 column chromatography. It showed that the purified gambier extracts (PGE) gave the higher DPPH radical scavenging activity and inhibition of peroxide than rutin BHT.

Even though gambier is also rich in polyphenols, it is not used traditionally in treating diabetes mellitus. Therefore, it is important to study its potential as an inhibitor of $\alpha$ glucosidase - carbohydrate hydrolizing enzyme. This study will examine the $\alpha$-glucosidase inhibitory activity of ethanolic extract of leaves, twig, and comercial gambier from Southeast Aceh as one of antidiabetics medicine. It is hoped that bioactive compunds from gambier would effectively inhibiting the activity of $\alpha$-glucosidase enzymes and work like the mechanism of Glukobay® (acarbose) oral drugs in inhibiting blood glucose.

\section{Materials and Method}

\subsection{Materials}

$\alpha$-glukosidase, Glucobay® (acarbose), etanol p.a, bovin serum albumin, aquabidest, DMSO, phosphate buffer, natrium buffer, $\mathrm{NaOH}, \mathrm{Na}_{2} \mathrm{CO}_{3}$ and $\mathrm{HCl}$ was purchased from EMerck.

Fresh leaves and twigs, and comercial gambier product was purchased from central production in Kuta Panjang, Istiqamah, Darul Hasanah, Southeast Aceh.

\subsection{Sample Preparation}

Fresh leaves and twigs of gambier was washed with running water and air dried for 7 days. The aired dried leaves, twig and gambier commercials product was then completely 
dried in oven at $40^{\circ} \mathrm{C}$, then grounded (AOAC 1984). The dried sample was then analyzed for moisture content. Each treatment was repeated 3 times.

\subsection{Extraction of Gambier}

Extraction of sample with maseration technique was done using standard method of Ministry of Health of Indonesian Republic (2009). Each sample was weighed 500 grams, ethanol solvent added p.a 1:10, kept for 2 x 24 hours, filtering was done every 24 hours, and the macerate was re-immersed with the same amount and type of solvent. The obtained filtrate is concentrated with a rotary evaporator, to obtain a concentrated or dry extract.

\subsection{Analysis of $\alpha$-Glucosidase Inhibitory Activity}

The analysis of the inhibitory activity of the $\alpha$-glucosidase enzyme refers to method developed by [12] and [13]. Each sample was dissolved in a dimethyl sulphoxide (DMSO) solvent with concentrations of $15.63,31.25,62.5,125,250,500$ and $1000 \mu \mathrm{g} \mathrm{mL}-1$. The enzyme solution was prepared by dissolving $1.0 \mathrm{mg} \alpha$-glucosidase in a phosphate buffer solution ( $\mathrm{pH} 7$ ) containing $200 \mathrm{mg}$ of bovine serum albumin. Before use as much as $1 \mathrm{ml}$ enzyme diluted 25 times with phosphate buffer $(\mathrm{pH} 7)$. The reagent mixture comprises $50 \mu \mathrm{L}$ phosphate buffer solution $0.1 \mathrm{M}(\mathrm{pH} 7.0), 25 \mu \mathrm{L} \rho$-nitrophenyl $\alpha$-D-glucopyranose ( $\rho$-NPG) $10 \mathrm{mM}$ as substrate, $10 \mu \mathrm{L}$ sample solution in dimethyl sulfoxide, and $25 \mu \mathrm{L}$ enzyme $\alpha-$ glucosidase 0.04 units $\mathrm{mL}-1$. Thereafter, the reagent mixture was incubated at $37^{\circ} \mathrm{C}$ for 30 minutes. The enzyme reaction was discontinued by adding $100 \mu \mathrm{L}$ of sodium carbonate (Na2CO3) $0.2 \mathrm{M}$ and the absorbance of p-nitrophenol was measured at a $410 \mathrm{~nm}$ wavelength using a microplate reader.

Positive control of acarbose known as Glucobay ${ }^{\circledR}$ is made by dissolving the tablet of acarbose in phosphate buffer $(\mathrm{pH} 7)$ and $\mathrm{HCl} 2 \mathrm{~N}$. The concentration of standard $1 \%$ acarbose solution used was made from a tablet of the diluted acarbose in aquadest and $\mathrm{HCl} 2 \mathrm{~N}(1: 1)$. Ratio of acarbose tablet weight with aquadest and $\mathrm{HCl} 2 \mathrm{~N}$ was $1: 100$. Then acarbose solution was centrifugated and supernatant were used as standard. The standard solution was given the same treatment as the ethanolic extract. Each treatment was repeated 3 times. Every gambier ethanolic extract tested for $\alpha$-glucosidase inhibitory activity (in $\%$ inhibition), which analized using the formula,

$$
\% \text { inhibisi }=(\mathrm{C}-\mathrm{S}) / \mathrm{C} \times 100
$$

$\mathrm{C}$ is the absorbance of the solution in the absence of the extract (control) and $\mathrm{S}$ is the absorbance of the solution by giving the extract from the sample.

The value of $\mathrm{IC}_{50}$ is obtained by plotting the log of concentration versus percent inhibition using the regression equation. The value of IC50 is the concentration value that inhibits 50\% of enzyme work.

\section{RESULTS AND DISCUSSION}

\subsection{Moisture Content of Gambir Extract}

Simplisia of dried leaves, twigs, and commercially gambier product were subjected to oven drying at $40{ }^{\circ} \mathrm{C}$ for 1,5 hour before tested for moisture content. Table 1 . Listed the 
mositure content of grounded dried gambier. The measurement was important to evaluate the effect of drying process on the removal of water content that could help the growth of microorganism such as bacteria, yeast and mold from the grounded gambier storage if they were kept for longer periods. Based on Regulation of Ministry of Health of Indonesian Republic (2009), moisture content for Traditional Herbal Medicine is maximum 10\%. The moisture content for gambier leaves and twigs were below the standard, while the commercial gambier product contained $12.023 \%$ of water because its still newly made. The moisture content couldn't totally remove even after oven drying.

Table 1. Moisture content of dried gambier

\begin{tabular}{cc}
\hline Type of sample & Moisture content (\%) \\
\hline Gambier leaves (DG) & 3.017 \\
Gambier twigs (RG) & 3.012 \\
Commercial Gambier (GT) & 12.023 \\
\hline
\end{tabular}

\subsection{Rendements of Gambier Ethanolic Extract}

Rendements of gambier extract were obtained from maceration process using ethanol as liquid solvent which repeated 3 times, every 24 hour. Ethanol were choosen because of it solubity and avaiability character. Table 2 shown the rendements of each gambier ethanolic extract, in $\mathrm{mg} / \mathrm{mg}$ dried weight of gambier part. The highest rendements from commercial gambier was 6.433

Table 2. Rendements of gambier ethanolic extract

\begin{tabular}{cl}
\hline Type of sample & $\begin{array}{l}\text { Rendements (mg/mg } \\
\text { DW) }\end{array}$ \\
\hline Gambier leaves (DG) & 3.847 \\
Gambier twigs (RG) & 1.444 \\
Commercial Gambier (GT) & 6.433 \\
\hline
\end{tabular}

\section{3 $\alpha$-Glucosidase inhibitory activity of Gambier Ethanolic Extract}

Figure 1 expressed the inhibition of alpha glokusidase enzyme on ethanol extract of gambier leaves. The highest percentage was resulting at $1000 \mathrm{ppm}$ was $96,446 \%$ with IC50 values 35,532 ppm.

The activity of alpha glucosidase on twigs ethanol extract was shown in Figure 2 . The best inhibitory activity was 70,699\% at 1000 ppm. IC values analysis resulting at 497,732 ppm. This values was inappropiate for inhibiting glucose metabolic pathway in blood as its gave values more than $150 \mathrm{ppm}$, while the maximum standard for IC values was $150 \mathrm{ppm}$.

From Figure 1 and 2 we could compared the alpha glucosidase inhibition activities of freah leaves and twigs which gave different potency of gambier ethanolic extract. The concentrations of $15.63,31.25,62.5,125,250,500$ and $1000 \mu \mathrm{g} \mathrm{mL}-1$ used in enzyme preparation with DMSO gave best result of inhibitory activity only on gambier leaves extract with IC50 values of $35,532 \mathrm{ppm}$. Meanwhile, the twig ethanolic extract gave less enzyme inhibitory activity with higher in IC50 values. The alpha glucosidase inhibition activity from 
fresh gambier leaves and twigs ethanolic extract has potencial appliction for inhibiting the glucose metabolic pathway, that can function as one of antidiabets. Gambier leaves better used dried as it could be saved in low moisture content for longer period.

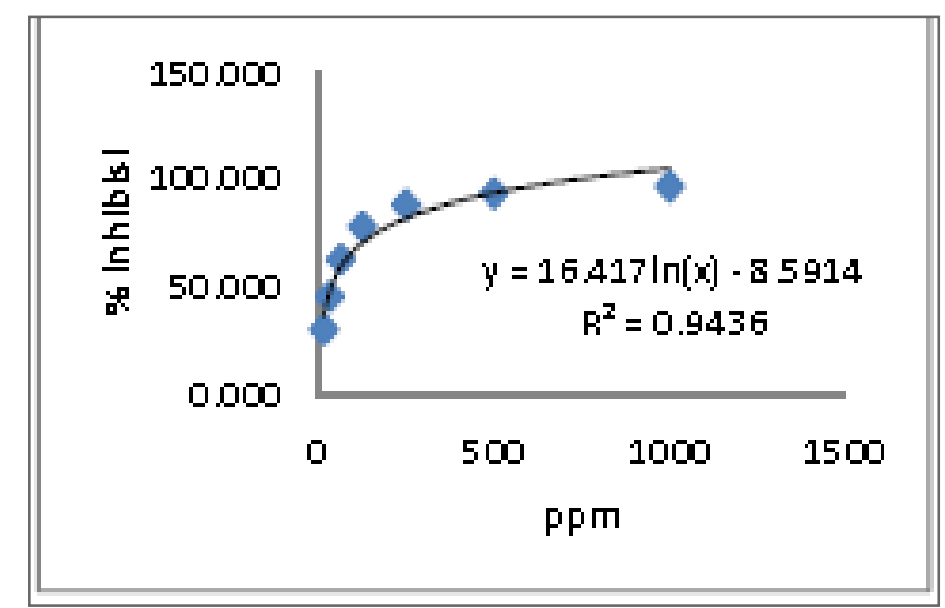

Fig. 1 Inhibitory activity of extract ethanolic gambier leaves.

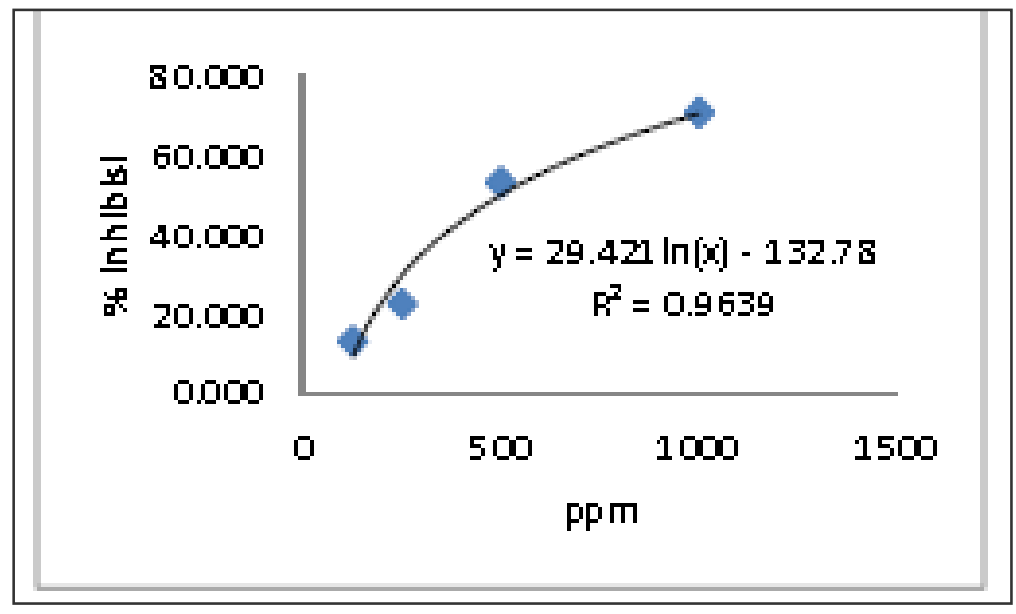

Fig. 2 Inhibitory activity of ethanolic extract gambier twigs.

These results from Figure 1 and 2 was predicted before, as from pre-experiments we got $1,444 \mathrm{mg} / \mathrm{mg}$ DW rendements of twigs ethanolic extract, while from leaves we gor rendements $3,874 \mathrm{mg} / \mathrm{mg} \mathrm{DW}$. The highest rendements was obtained from gambier commercials product $(6,433 \mathrm{mg} / \mathrm{mg} \mathrm{DW})$, but it's analysis resulted minus values (Data not shown here) on alpha glucosidase inhibitory activity because the product still contained high moisture which prevent the inhibition of glucosidase enzyme. 


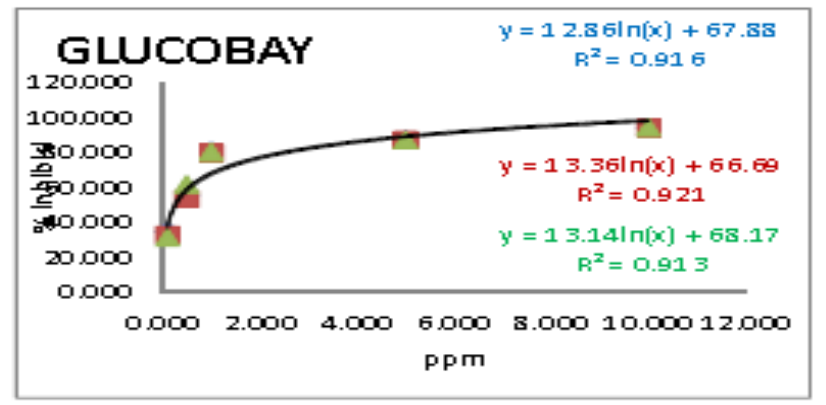

Fig. 3 Inhibitory activity of positive control of Glucobay ${ }^{\circledR}$ (acarbose).

The gambier extract was also compared with positive control of diabetics drug (Glucobay ${ }^{\circledR}$ ) which contained $50 \mathrm{mg}$ of acarbose in each tablets. The concentration of acarbose $10 \mathrm{ppm}$ could inhibited the alpha glucosidase activity by $94,095 \%$. This mean that the fresh gambier leaves ethanolic extract will work the same as acarbose in inhibiting the glucose metabolic. Gambier leaves from Southeast Aceh has good potencial to be used as one of traditioal medicine for curing diabetics type II disease. The extract of gambier leaves could be kept in form of tablet of dried extract for application as herbal alternative medicine for antidiabetics and other porposes.

\section{Conclusions}

Based on the research that has been done can be concluded that:

1. Water content analysis on three types of leaf samples, twigs and gambier products shows the value below the quality standard that is for leaves samples and twig gambier. As for the traditional gambier water content exceeds that set above $10 \%$.

2. The analysis of rendement shows that the yield content obtained after the rotary evaporator process is very little walaupu in the extraction process with the process of maceration has been done repetition and merging extraction results. The rendements content of the three gambier samples were DG 3,847 gr, RG 1,444 gr and GT 6,433 gr. And IC50 = 35.50 ppm

3. Analysis of alpha glucosidase inhibition is the determinant for antidiabetic studies of gambier extract, where the higher the sugar content in the blood the percent of alpha glucosidase inhibition is also increasing. This indicates that the extract of the resulting gambier ethanol has the potential of being a herbal drug inhibiting diabetes.

\section{REFERENCES}

[1] Z. M. Dastjerdi, F. Namjoyan, and M. Ebrahim Azemi, "Alpha Amylase Inhibition Activity of Some Plants Extract of Teucrium Species,” Eur. J. Biol. Sci., vol. 7, no. 1, pp. 26-31, 2015.

[2] International Diabetes federation, IDF Diabetes Atlas, Sixth Edit. 2013.

[3] World Health Organization, General Guidelines for Methodologies on Research and Evaluation of Traditional Medicine, vol. 1. 2000.

[4] R. R. Holman, C. A. Cull, and R. C. Turner, "A randomized double-blind trial of acarbose in 
type 2 diabetes shows improved glycemic control over 3 years (UK Prospective Diabetes Study 44)," Diabetes Care, vol. 22, no. 6, pp. 960-964, 1999.

[5] N. Saito, H. Sakai, S. Suzuki, H. Sekihara, and Y. Yajima, "Effect of an $\alpha$-glucosidase inhibitor (voglibose), in combination with sulphonylureas, on glycaemic control in type 2 diabetes patients," J. Int. Med. Res., vol. 26, no. 5, pp. 219-232, 1998.

[6] M. Toeller, " $\alpha$-Glucosidase inhibitors in diabetes: efficacy in NIDDM subjects," Eur. J. Clin. Invest., vol. 24, no. S3, pp. 31-35, 1994.

[7] J. a Sneha and S. Chaudhari, "Alpha amilase inhibitroty and hypoglycemic activity of Clerodendrone multiforum Linn. Stems," Asian J. Pharm. Clin. Res., vol. 4, no. 2, pp. 2-5, 2011.

[8] A. Achmad, J. Kassim, T. K. Suan, R. C. Amat, and T. L. Seey, "Equilibrium, kinetic and thermodynamic studies on the adsorption of direct dye onto a novel green adsorbent developed from Uncaria gambir extract," J. Phys. Sci., vol. 23, no. 1, pp. 1-13, 2012.

[9] S. Sabarni, “Teknik pembuatan gambir (Uncaria gambir Roxb) Secara Tradisional,” Elkawnie J. Islam. Sci. Technol., vol. 1, no. 1, pp. 105-112, 2015.

[10] F. Apea-Bah et al., "Assessment of the DPPH and a-glucosidase inhibitory potential of gambier and qualitative identification of major bioactive compound," J. Med. Plants Res., vol. 3, no. 10, pp. 736-757, 2009.

[11] R. Rauf, U. Santoso, and S. Suparmo, "Aktivitas Antioksidan Ekstrak Gambir yang Dipurifikasi Menggunakan Kromatografi Kolom Sephadex LH-20,” Agritech, vol. 32, no. 2, pp. 167-172, 2012.

[12] S. Sugiwati, L. B. S. Kardono, and M. Bintang, "Alpha-Glucosidase inhibitory activity and hypoglycemic effect of Phaleria macrocarpa fruit pericarp extracts by oral administration to rats," Journal of Applied Sciences, vol. 6, no. 10. pp. 2312-2316, 2006.

[13] S. Sancheti, S. Sancheti, and S. Y. Seo, "Chaenomeles sinensis: A potent Alpha-and Betaglucosidase inhibitor,” Am. J. Pharmacol. Toxicol., vol. 4, no. 1, pp. 8-11, 2009. 